\title{
The Intracellular Cryoprotectant Effects in Preserving Goramy Spermatozoa after Two Days Sub-Zero Freezing
}

\author{
Abinawanto $^{1}$, Nisa Fitrianingrum ${ }^{1}$, Retno Lestari ${ }^{1}$, Agung Sudaryono ${ }^{2}$, Rita Rostika ${ }^{3}$, \\ and Yushinta Fujaya ${ }^{4}$ \\ ${ }^{1}$ Biology Graduate Study Program, Faculty of Mathematics and Natural Sciences, Universitas Indonesia, Depok, Indonesia \\ ${ }^{2}$ Aquaculture Study Program, Diponegoro University, Semarang, Indonesia \\ ${ }^{3}$ Faculty of Fisheries and Marine Science, Padjadjaran University, Bandung, Indonesia \\ ${ }^{4}$ Faculty od Marine Science and Fisheries, Hasanudin University, Makassar, Indonesia \\ Correspondence to: abinawanto.ms@sci.ui.ac.id
}

\begin{abstract}
Abinawanto Abinawanto, Nisa Fitrianingrum, Retno Lestari, Agung Sudaryono, Rita Rostika, and Yushinta Fujaya. 2015. The Intracellular Cryoprotectant Effects in Preserving Goramy Spermatozoa after Two Days Sub-Zero Freezing, Aquacultura Indonesiana, 16 (1): 16-21. The spermatozoa quality of goramy after $2 \mathrm{~d}$ sub-zero freezing was examined. The quality of spermatozoa examined included motility, viability, and abnormality. We aimed to determine the optimum concentration of glycerol protecting spermatozoa during preservation. We used $0 \%, 1 \%, 3 \%, 5 \%, 7 \%$, and $9 \%$ of glycerol, respectively. Sperms were diluted by the combination of glycerol and fish ringer ( 1 part of sperm +3 part of solvent). The dilute sperms were then equiliberated at $4{ }^{\circ} \mathrm{C}$ for $45 \mathrm{~min}$, and were freezed at $-34^{\circ} \mathrm{C}$ for $2 \mathrm{~d}$. Thawing was then carried out at $30^{\circ} \mathrm{C}$ for $2 \mathrm{~min}$. Based on Dunnet test, $5 \%$ of glycerol was the optimum concentration maintaining spermatozoa motility $(75.95 \pm 4.76) \%$.
\end{abstract}

Keywords: Glycerol; Osphronemus goramy; Spermatozoa motility; Sub-zero freezing; Viability and Abnormality

\section{Introduction}

According to Sunarma et al. (2007), Osphronemus goramy is very important commodity of the local freshwater fish in Indonesia. However, goramy fish aquaculture is still traditionally, and cause declining in genetic material quality (Alam et al., 2002). Accordingly, cryopreservation effort is needed as an alternative method for preserving the quality of genetic materials such as spermatozoa, ovum and embryos under low temperature condition (Fickle et al., 2007). Research on cryopreservation of fish spermatozoa has been reported such as in salmon (Kusuda et al., 2005) and catfish (Urbanyi et al., 1999). Cryoprotectant and extender are needed during cryopreservation. Christensen and Tiersch (2005) were reported that glycerol, Dimethyl Sulphoxide (DMSO), Propilene Glycol, and methanol can be used as the cryoprotectant. While, fish ringer have been used as the extender (Park and Chapman, 2005). Horvarth and Urbanyi (2000) have administered glycerol and fish ringer to preserve spermatozoa of Clarias gariepinus. Whereas, Kyoung Ho Kang et al. (2004) have used 5\%, 10\%, 15\%, and $20 \%$ of glycerol for preserving spermatozoa of
Thamnaconus septentrionalis. On the other hand, Muchlisin et al. (2004) have studied the combination effect of $5 \%, 10 \%$, and $15 \%$ of glycerol and fish ringer on Mystus nemurus spermatozoa under low temperature. Accordingly, the studies of cryopreservation using variation of cryoprotectant and extender are very important.

Studies of cryopreserved goramy spermatozoa have been reported. Dimethyl Sulfoxide (DMSO) has been used as the cryoprotectant for preserving goramy spermatozoa in liquid nitrogen for $24 \mathrm{~h}$ (Abinawanto et al., 2011). Besides, sucrose could also be used as the extender and cryoprotectant (Abinawanto et al., 2012 ${ }^{\mathrm{a}}$ ). It has been reported by Abinawanto et al. $\left(2012^{\mathrm{b}}\right)$ that skim milk play an important role as the extracellular cryoprotectant. However, currently lack information is available on the glycerol effect as the intracellular cryoprotectant in preserving goramy spermatozoa after $2 \mathrm{~d}$ sub-zero freezing.

The aim of this study was to evaluate the intracellular cryoprotectant effects (motility, viability, and abnormality) at the optimum concentration of glycerol as the cryoprotectant. 


\section{Materials and Methods}

The study was conducted in June 2010 November 2010, at the Genetics Laboratory, Biology Department, Faculty of Mathematics and Natural Sciences, Universitas Indonesia, Depok, West Java Provinces, Indonesia

\section{Fish Preparation}

Twenty four mature males of Osphronemus goramy were bought from the private commercial hatchery, Parung-Bogor, West Java, Indonesia. All fishes were acclimatized for $14 \mathrm{~d}$ in one-4000-L square concrete cement fish pond till they attain $2.5-4 \mathrm{~kg}$ size in the indoor Aquatic Biology laboratory, Biology Department, Faculty of Mathematics and Natural Sciences, Universitas Indonesia, Depok, West Java Province. The fishes were grouped of 6 fishes and were stocked in 7 square concrete cement fish pond $(1000-\mathrm{L})$. The fish pond were equipped with closed re-circulation system and a black plastic mesh lid to minimize disturbances and prevent fish from jumping out. Six experimental group based on glycerol concentration were assigned to four times replication in a completely randomized design. Fishes were fed with the commercial diet and leaf of Allocasia macrorrhiza two times daily ad libitum at 08:00 and 17:00.

\section{Fish ringer preparation}

Fish ringer solution was prepared according to the method of Ginzburg (1972). A fish ringer stock solution was prepared by dissolving $3.25 \mathrm{~g} \mathrm{NaCl} ; 0.125 \mathrm{~g} \mathrm{KCl} ; 0.175 \mathrm{~g}$ $\mathrm{CaCl}_{2} \cdot 2 \mathrm{H}_{2} \mathrm{O}$; and $0.1 \mathrm{~g} \mathrm{NaHCO}_{3}$ with aquabidest up to $500 \mathrm{~mL}$. The extender fish ringer solution was then kept at $4^{\circ} \mathrm{C}$.

\section{Activator solution preparation}

The activator solution was prepared based on the method of Perchec et al. (1995) by diluting $45 \mathrm{mM} \mathrm{NaCl}, 5 \mathrm{mM} \mathrm{KCl}$, and $30 \mathrm{mM}$ Tris with aquabidest up to $100 \mathrm{~mL}$

\section{$0.5 \%$ Eosin-Y solution preparation}

The $0.5 \%$ of Eosin-Y solution was prepared according to the method of WHO (1988), by diluting $0.5 \mathrm{~g}$ of the Eosin-Y with aquabidest up to $100 \mathrm{~mL}$.

\subsection{M of Phosphate buffer solution pH 6.8 preparation}

The Phosphate buffer solution was prepared by dissolving $5.34 \mathrm{~g} \mathrm{Na}_{2} \mathrm{HPO}_{4} \cdot 2 \mathrm{H}_{2} \mathrm{O}$ with aquabidest up to $200 \mathrm{mLl}$, and by dissolving $4.08 \mathrm{~g} \mathrm{KH}_{2} \mathrm{PO}_{4}$ with aquabidest up to $200 \mathrm{mLl}$. $\mathrm{Na}_{2} \mathrm{HPO}_{4} \cdot 2 \mathrm{H}_{2} \mathrm{O}$ solution was then added to $\mathrm{KH}_{2} \mathrm{PO}_{4}$ solution until the $\mathrm{pH}$ reach 6.8. The Phosphate buffer solution was then kept at $4{ }^{\circ} \mathrm{C}$.

\section{Giemsa solution preparation}

The Giemsa solution was prepared based on WHO (1988), by diluting one part of the Giemsa stock solution and 10 parts of the Phosphate buffer solution $\mathrm{pH}$ 6.8. The mixed solution was then filtered by Whatman filter paper number one.

\section{Collection of the ejaculated sperm/semen}

The sperm was collected by hand stripping method, $12-15 \mathrm{~h}$ after injected intramuscularly with GnRH-analog (Ovaprim Syndel) at a single-dose of $0.2 \mathrm{~mL} / \mathrm{kg}$ body weight according to modification method of Sunarma et al. (2007), and was put in $1.5 \mathrm{~mL}$ of cryotube.

\section{Semen/sperm Dilution}

According to Akcay (2004), ratio among the ejaculated semen/sperm and the solvent was 1: 3 . The sperm was added to the solvent solution in the cryotube. The compostition of each component of the solvent solution and the ejaculated sperm was seen in Table 1.

Table 1. Composition of Semen/sperm, Fish ringer and glycerol (G) of experimental group

\begin{tabular}{lcccccc}
\hline \multirow{2}{*}{ Composition } & \multicolumn{7}{c}{ Experimental group } \\
\cline { 2 - 7 } & \multicolumn{1}{c}{$1 \% G$} & $3 \% G$ & $5 \% G$ & $7 \% G$ & $9 \% G$ \\
\hline Semen/Sperm $(\mu \mathrm{L})$ & 50 & 50 & 50 & 50 & 50 & 50 \\
Fish Finger Solution $(\mu \mathrm{L})$ & 150 & 148 & 144 & 140 & 136 & 132 \\
Glycerol/G $(\mu \mathrm{L})$ & 0 & 2 & 6 & 10 & 14 & 18 \\
\hline
\end{tabular}

$* \mathrm{C}=$ control group; $* * 1 \% \mathrm{G}, 3 \% \mathrm{G}, 5 \% \mathrm{G}, 7 \% \mathrm{G}, 9 \% \mathrm{G}=$ treatment group. 


\section{Semen/sperm Equilibration}

The diluted sperm was then equilibrated at $4^{\circ} \mathrm{C}$ for $45 \mathrm{~min}$ (Akcay et al., 2004 and Bozkurt et al., 2005).

\section{Semen/sperm Freezing}

The diluted sperm was freezing at $-34^{\circ} \mathrm{C}$ for $48 \mathrm{~h}$ (Changjiang Huang et al., 2004).

\section{Semen/sperm Thawing}

The frozen sperm was incubated at $30^{\circ} \mathrm{C}$ for 2 min. (Akcay et al., 2004 and Bozkurt et al., 2005).

\section{Semen/sperm Evaluation and Spermatozoa Analyses}

Fresh semen/sperm color was observed by visual, whereas sperm volume was measured by the cryotube with scale. Fresh sperm $\mathrm{pH}$ was measured by standardized $\mathrm{pH}$ paper $(\mathrm{pH}$ range 510). The parameter of the spermatozoa analyzed were spermatozoa viability, abnormality, and motility, respectively. All of the spermatozoa analyses parameters were observed under trinocular microscope (Boeco) equipped with the digital eye piece camera (MDCE-5a). This microscope was connected to the computer equipped by the image driving software (Scopephoto 2.0.4). Spermatozoa motility was analyzed by subjective method (Rurangwa et al. (2004), whereas spermatozoa viability and spermatozoa motility were analyzed by Salisbury and VanDemark method (1985).

\section{Data analysis}

All data were analyzed by KruskalWallis and Dunnet's multiple comparison test (Zar, 1974) using a statistic program of SPSS version 13 for Windows. All probability values were set at 0.05 level of significance.

\section{Results}

Fresh semen (FS) were milky white, $\mathrm{pH}$ $8.03 \pm 0.05$, and $0.45 \pm 0.10 \mathrm{~mL}$ of volume per ejaculate (Table 2). The viable or motile spermatozoa showed green color (Figure 1) on the sperm head, while the non-viable spermatozoa showed pink or red color on the sperm head (Figure 1). Both of viable and non-viable spermatozoa were found in all treatment groups and control. However, percentage of spermatozoa viability were different quantitatively either among treatment groups or between control and treatment groups. On the other hand Figure 2 were shown the normal spermatozoa
(A) and many variations of abnormal spermatozoa such as macrocephalus (B), microcephalus, folding tail spermatozoa (C), and broken tail spermatozoa. Either the normal or abnormal spermatozoa morphologically were also found in all treatment groups and control. However, the percentage of spermatozoa normal and abnormal were different, among treatment groups aor between control and treatment groups.

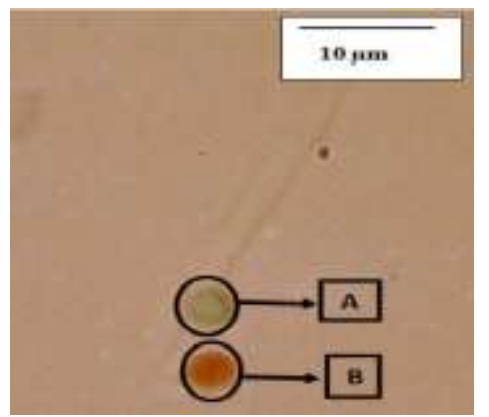

Figure 1. Spermatozoa viable (A); spermatozoa nonviable (B); 10x40 162x95 mm (96 x 96 DPI)

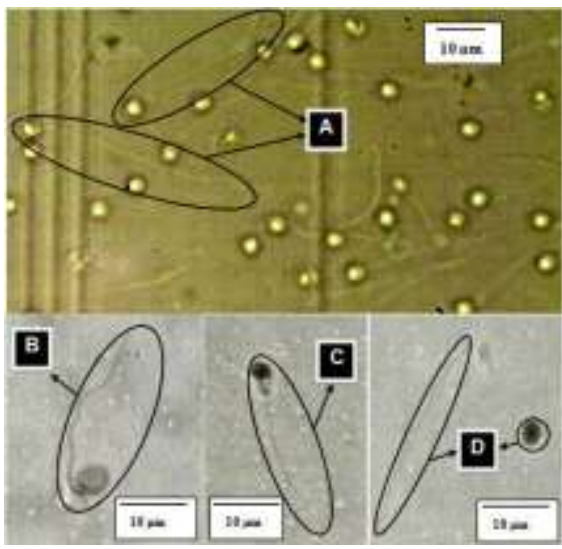

Figure 2. Normal spermatozoa (A); Macrocephalus spermatozoa (B); Folding tail spermatozoa (C); Broken tail spermatozoa (D); 10x40 $162 \times 204 \mathrm{~mm}^{2}(96 \times 96 \mathrm{DPI})$

The percentage of post-thaw spermatozoa motiliy in control; and in various glycerol concentration of $1 \%, 3 \%, 5 \%, 7 \%$, and $9 \%$, were: $(59.31 \pm 6.38) \%,(63.83 \pm 4.79) \%,(66.43 \pm 6.82) \%$, $(75.95 \pm 4.76) \%,(68.90 \pm 4.65) \%$, and $(69.93 \pm$ $8.16) \%$, respectively (Table 3). Post-thaw spermatozoa viability in control; and in various glycerol concentration of $1 \%, 3 \%, 5 \%, 7 \%$, and $9 \%$, were: $(71.33 \pm 5.39) \%,(76 \pm 6.10) \%,(73.83 \pm$ $6.43) \%,(75.50 \pm 5.43) \%$, $(70.50 \pm 6.22) \%$, and $(69.83 \pm 14.23) \%$, respectively (Table 3$)$. On the other hand, post-thaw spermatozoa abnormality in control; and in various glycerol concentration of $1 \%, 3 \%, 5 \%, 7 \%$, and $9 \%$, were: $(15.33 \pm 5.57) \%$, $(19.50 \pm 4.04) \%,(19.17 \pm 5.95) \%,(14.83 \pm$ $2.79) \%,(16.50 \pm 3.83) \%$, and $(19.67 \pm 3.50) \%$, respectively (Table 3 ). 
Table 2. Fresh Semen/sperm evaluation and spermatozoa analyses of Osphronemus goramy spermatozoa, before freezing

\begin{tabular}{ccccccc}
\hline Paramater & Color & Volume $(\mathrm{mL})$ & $\mathrm{pH}$ & Viability (\%) & Abnormality (\%) & Motility $(\%)$ \\
\hline & Milky white & $0.45 \pm 0.10$ & $8.03 \pm 0.05$ & $85.16 \pm 1.94$ & $15.67 \pm 2.16$ & $74.12 \pm 5.26$
\end{tabular}

Values are means \pm SD of four replicates.

Table 3. Viability, Abnormality, and Motility of Osphronemus goramy spermatozoa, $48 \mathrm{~h}$ after sub-zero freezing

\begin{tabular}{lcccccc}
\hline \multirow{2}{*}{ Paramater } & \multicolumn{5}{c}{ Experimental group } \\
\cline { 2 - 7 } & $C$ & $1 \% G$ & $3 \% G$ & $5 \% G$ & $7 \% G$ & $9 \% G$ \\
\hline Viability $\left.(\%)^{\mathrm{l}}\right)$ & $71.33 \pm 5.39^{\mathrm{a}}$ & $76 \pm 6.10^{\mathrm{a}}$ & $73.83 \pm 6.43^{\mathrm{a}}$ & $75.5 \pm 5.43^{\mathrm{a}}$ & $70.5 \pm 6.22^{\mathrm{a}}$ & $69.83 \pm 14.23^{\mathrm{a}}$ \\
Abnormality (\%) & $15.33 \pm 5.57^{\mathrm{a}}$ & $19.5 \pm 4.04^{\mathrm{a}}$ & $19.17 \pm 5.95^{\mathrm{a}}$ & $14.83 \pm 2.79^{\mathrm{a}}$ & $16.5 \pm 3.83^{\mathrm{a}}$ & $19.67 \pm 3.50^{\mathrm{a}}$ \\
Motility (\%) & $59.31 \pm 6.38^{\mathrm{a}}$ & $63.83 \pm 4.79^{\mathrm{a}}$ & $66.43 \pm 6.82^{\mathrm{ab}}$ & $75.95 \pm 4.76^{\mathrm{b}}$ & $68.90 \pm 4.65^{\mathrm{ab}}$ & $69.93 \pm 8.16^{\mathrm{ab}}$ \\
\hline
\end{tabular}

Values are means + SD of four replicates. Mean values having the same superscript are not significantly different $(P>0.05)$.

Based on Kruskal-Wallis test, there were not significant effect $(P>0.05)$ of various concentration of glycerol on post-thaw sperm viability and abnormality, respectively, but not on post-thaw motility $(P<0.05)$ compared to control (Table 3). According to the Dunnet test, the concentration of $5 \%$ of glycerol showed the highest post-thaw sperm motility (75.95 \pm 4.76)\%, although was significant different with other concentration group of $3 \%, 7 \%$ and $9 \%$ of glycerol, respectively.

\section{Discussion}

The concentration of $5 \%$ glycerol was shown the highest percentage spermatozoa motility $(75.95 \pm 4.76) \%, 2 \mathrm{~d}$ after sub-zero freezing. This finding was similar with the previous study (Horvarth and Urbanyi, 2000) when they preserved spermatozoa of Clarias gariepinus. On the other hand, post thaw motility in this study was lowered compared our previous study $\left(80.98 \%\right.$; Abinawanto et al. $2012^{\text {b }} ; 96.10 \%$; Abinawanto et al., 2013). However, post thaw motility in this study was higher than Brachydanio rerio (51\%; Harvey et al., 1982), Oreochromis mossambicus (70\%; Harvey, 1983), tilapian's fish (40\%; Chao et al., 1987), Cyprinus carpio (55\%; Akcay et al., 2004), Osteochiius hasseltii (63.33\%; Sunarma et al., 2007), and Osphronemus goramy (68.58\%; Abinawanto et al., 2011). Post thaw viability in the treatment group of $5 \%$ glycerol was $75.5 \pm$ $5.43 \%$, although was not significant different compared with other treatment groups and control, statistically. However, this finding was higher than previous reported in spermatozoa of Mystus nemurus (60\%; Muchlisin et al., 2004), Cyprinus carpio (20\%; Withler, 1982; 58\%;
Horton and Otto, 1976), and Osphronemus goramy (63.5\%; Abinawanto et al., 2011). Post thaw viability in this study on the other hand was lowered than our previous work in Barbonymus gonionotus spermatozoa (77.25\%; Abinawanto et al., 2009; 85.50; Abinawanto et al., 2013). The effect of $5 \%$ of glycerol can declined the post thaw abnormality $(14.83 \pm 2.79) \%$, better than other treatment group of glycerol concentration and control group, although those results were not significant different, statistically. Our previous study showed the higher spermatozoa abnormality (29\%; Abinawanto et al., 2011) when using the combination of $13 \%$ of DMSO + $189 \mathrm{M}$ extender. Post thaw abnormality in Barbonymus gonionotus spermatozoa was higher (45\%) when preserved in the combination of $6 \%$ of glucose $+10 \%$ of methanol (Abinawanto et al., 2009). However, the post thaw abnormality showed mearly similar (14\%) when the spermatozoa of Barbonymus gonionotus protected by the combination of $13 \%$ of egg yolk $+10 \%$ of methanol (Abinawanto et al., 2013).

Either all of treatment groups or control were shown the viable spermatozoa, motile spermatozoa, and abnormal spermatozoa, visually. However, the percentage of spermatozoa viability, motility and abnormality were different among treatment groups, or between control and treatment groups. The optimum condition of the treatment group (percentage of glycerol) was shown by the lowest percentage of spermatozoa abnormality (by reduced percentage of spermatozoa abnormality) after sub-zero freezing for $2 \mathrm{~d}$. Furthermore, the highest percentage of viability or motility of spermatozoa among the treatment groups or between control and treatment groups $2 \mathrm{~d}$ after sub-zero freezing also as the indicator of the 
optimum condition of percentage of glycerol as the cryoprotectant.

\section{Conclusion}

The data obtained in the present study indicate that $5 \%$ of glycerol was the optimum concentration as the cryoprotectant for preserving Osphronemus goramy spermatozoa at sub-zero freezing for $2 \mathrm{~d}$.

\section{Acknowledgement}

We would like to thank Directorate General for Higher Education, Department of National Education, Republic of Indonesia that had funded this study through the University of Indonesia Competitive Research Grant No. 240AT/DRPM-UI/N1.4/2008 for the financial support.

\section{References}

Abinawanto A., Fadhillah, and R. Lestari. 2009. The effect of glucose in various concentrations on sperm quality of Barbonymus gonionotus (Bleeker, 1850) 24 hours post-cryopreservation. The Journal of Reproduction and Development, 55 Suppl. September.

Abinawanto, M.D. Bayu, R. Lestari, and A. Sunarma. 2011. Spermatozoa quality of goramy fish, Osphronemus goramy Lacepede, 1801 twenty four hours postcryopreservation: The role of Dimethyl Sulfoxide (DMSO) as a cryoprotectant. Biota, 16:10-15

Abinawanto, K. Nurman, and R. Lestari. 2012 ${ }^{\mathrm{a}}$. The effect of sucrose on sperm quality of goramy fish, Osphronemus goramy Lacepede, 1801 two days postcryopreservation. Journal of Agricultural Science and Technology, B2:204-207.

Abinawanto, I. Anindita, and R. Lestari. 2012 Cryopreservation of spermatozoa of Osphronemus goramy fish using skim milk. International Journal of Engineering and Innovation Technology, 2(5):62-64.

Abinawanto, S. Rahayu, and R. Lestari. 2013. Cryopreservation of Java Barb (Barbonymus gonionotus spermatozoa using egg yolk as a cryoprotectant. Global Veterinary, 10(3): 318-321.

Akcay E., Y. Bozkurt, S. Secer, and N. Tekin. 2004. Cryopreservation of mirror carp semen. Turkey Journal Veterinary Animal Science, 28:837-843.
Alam, M.A., M.S.A. Akanda, and S. Alam. 2002. Comparison of genetic variability between a hatchery and a river population of Rohu (Labeo rohita) by allozyme electrophoresis. Pakistan Journal of Biological Science, 5(9):959-961.

Bozkurt, Y., E. Akcay, N. Tekin, and S. Secer. 2005. Effect of freezing techniques, extenders, and cryoprotectants on the fertilization rate of frozen rainbow trout (Oncorhyncus mykiss) sperm. The Israeli Journal of Aquaculture-Bamidgeh, 57: 1-6.

Changjiang Huang, Qiaoxiang Dong, R.B. Walter, and T.R. Tiersch. 2004. Sperm cryopreservation of green swordtail Xiphophorus helleri, a fish internal fertilization. Cryobiology, 48: 295-308.

Chao N.H., W.C. Chao, K.C. Liu, and I.C. Liao. 1987. The properties of tilapia sperm and its Cryopreservation. Journal Fish Biology, 30(2):107-118.

Christensen, J.M. and T.R. Tiersch. 2005. Cryopreservation of channel catfish sperm: effects of Cryoprotectant exposure time, cooling rate, thawing conditions, and maleto-male variation. Theriogenology, 63: 21032112.

Fickle, J, W. Asja, and L. Arne. 2007. Semen cryopreservation and the conservation of endangered species Europian Journal Wildlife Research, 53: 81-89.

Ginzburg, A.S. 1972. Fertilization in fishes and the problem of polyspermy. Israel Program for Scientific Translation, Jerusalem, 366 pp.

Harvey, B. 1983. Cryopreservation of Sarotherodon mossambicus spermatozoa. Aquaculture, 32:313-320.

Harvey, B., N.R. Kelley, and M.J. Ashwood-Smith. 1982. Cryopreservation of zebrafish spermatozoa using methanol. Canada Journal Zoology, 60: 1867-1870.

Horton, H.F. and A.G. Otto. 1976. Cryopreservation of fish spermatozoa and ova. Journal of Fish Resources Board Canadian, 33: 995-1000.

Horvath A. and B. Urbanyi. 2000. The effect of cryoprotectans on the motility and fertilizing capacity of cryopreserved African catfish, Clarias gariepinus (Burchell 1882) sperm. Aquaculture Research, 31: 317-324.

Horvath, A., E. Miskolczi and B. Urbanyi. 2003. Cryopreservation of common carp sperm. Aquatic Living Resources, 16: 457--460.

Huang C., Q. Dong, R.B. Walter, and T.R. Tiersch. 2004. Sperm cryopreservation of green swordtail Xiphophorus helleri, a fish internal fertilization. Cryobiology, 48: 295-308.

Kusuda, S., N. Koide, H. Kawamula, T. Teranishi, J.I. Nakajima, E. Yamaha, K. Arai, and H. Ohta. 2005. Cryopreservation diluents for 
spermatozoa of Sakhalin taimen Hucho perryi. Fisheries Science, 71: 293-298.

Kyoung Ho Kang, K.H. Kho, Z.T. Chen, J.M. Kim, and Z.F. Zhang. 2004. Cryopreservation of file fish (Thamnaconus septentrionalis Gunther, 1877) sperm. Aquaculture Research, 35: 1429-1433.

Muchlisin, Z.A., R. Hashim, and A.S.C. Chong. 2004. Preliminary study on cryopreservation of tropical bagrid catfish (Mystus nemurus) spermatozoa: the effect of extender and cryoprotectant on the motility after short-term storage. Theriogenology, 62: 25-34.

Park, C. and F.A. Chapman. 2005. An extender solution for the short-term storage of Sturgeon semen. North American Journal of Aquaculture, 67: 52-57.

Perchec G., C. Jeulin, J. Cosson, F. Andre, and R. Billard. 1995. Relationship between sperm ATP content and motility of carp spermatozoa. Journal of Cell Science, 108: 747-753.

Rurangwa, E., D.E. Kime, F. Ollevier and J.P. Nash. 2004. Review article: The measurement of sperm motility and factors affecting sperm quality in cultured fish. Aquaculture, 234: 1-28.
Salisbury, G.W. and N.L. VanDemark. 1985. Reproductive physiology and induced breeding: $869 \mathrm{pp}$.

Sunarma, A., D.W. Hastuti, dan Y. Sistina. 2007. Penggunaan ekstender madu yang dikombinasikan dengan krioprotektan berbeda pada pengawetan sperma ikan nilem (Indonesian Sharkminnow, Osteochiius hasseltii Valenciennes, 1842). Konferensi Aquaculture Indonesia 2007, Surabaya, 5-7 Juni, 2007. Masyarakat Akuakultur Indonesia, Surabaya, pp. 1-9.

Urbanyi, B., A. Horvarth, Z. Varga, and L. Horvarth. 1999. Effect of extenders on sperm cryopreservation of African catfish, Clarias gariepinus (Burchell, 1882). Aquaculture Research, 30: 145-151.

WHO (World Health Organization). 1988. Penuntun laboratorium WHO untuk pemeriksaan semen manusia dan interaksi semen-getah serviks. Balai Penerbit Fakultas Kedokteran Universitas Indonesia, Jakarta, 78 pp.

Withler, F.C. 1982. Cryopreservation of spermatozoa of some freshwater fishes cultured in South and Southeast Asia. Aquaculture, 26: 395-398.

Zar, J.H. 1974. Biostatiscal analysis. Prentice-Hall Inc., London, 620 pp. 